Papers were read on the following subjects:

I. Note on Sawfly Larva, Hylotoma dulciaria; by Rev. T. W. Fyles. ham.

2. On the Stridulation of Geotrupes Blackburnii; by Mr. A. W. Han-

3. Notes on the Genus Colias; by Capt. G. Geddes.

4. The Home of Chionobas jutta; by Rev. T. W Fyles.

5. Notes on Larva of Mallota posticata; by Mr. Laurence Reed.

6. On Destruction of Insects by Electric Light; by Professor E. W. Claypole.

An interesting letter was also read from Miss Eleanor A. Ormerod, Consulting Entomologist of the Royal Agricultural Society, with information on the recent occurrence of the Hessian Fly in England.

\title{
NOTE ON WESTERN SPHINGIDA.
}

BY A. R. GROTE, A. M.

It is one of the pleasures which we older Entomologists alone feel to its full extent, when a well written paper, full of matter, falls under our notice on a favorite subject. Such a pleasure I experienced on receiving the June No. of the "old reliable" Canadian Entomologist, and the Rev. W. J. Holland's paper on our Sphingidæ opened before me. Supplementing, as it does in various points, Professor Fernald's valuable pamphlet, it will be welcome to all interested in the beautiful study of our Hawk Moths. Upon these I need not further dwell. I wish here to point out, in reference to the interesting remarks on our Western Sphingidæ, that on page 8 of my "New Check List" I say that I am indebted to Mr. Henry Edwards for various assistance, and that "I have received from the same Entomologist information as to the synonymy of certain Western Sphingidæ." Now the only two which have any synonymy beyond the original name are Occidentalis and Vancouverensis, and these are the ones meant. In fact the only Western form I ever possessed in my own collection was a specimen of $S$. perelegans, which seemed to me undoubtedly a distinct species, nor have I ever made any study of our Western forms. In my "New Check List" I omitted the use of the dash (-), which I have generally used (following Leconte) in my shorter 
lists after species unknown to me in nature. In my paper in July No., the locality, "West Coast," belongs to the preceding species perelegans, and a dash should follow Vancouverensis, as to the synonymy of which, as well as its validity as a species, I was indebted to Mr. Hy. Edwards for information. As will be seen by the absence of the dash after perelegans, as well as the wrong position given by me to Vancouverensis, the locality has been misplaced, as I give no locality to species unknown to me in this last list. Mr. Edwards quite naturally was our authority as to the Californian species. Since Mr. Butler considers the various Asiatic forms of Triptogon as local, rather than true species, I thought it might be so with occidentalis; but it may well be a mere variety, as Mr. Holland considers it. If I remember, Mr. Edwards originally described it as a geographical variety of modesta, which may be true if no typical modesta occur in California, and although this var. occidentalis may also be found in the East. This species will have then received four names (two applied to varieties) since Cablei from Louisiana, the larva on water plants, seems nothing but modesta, which its author did not know.

Mr. Holland's note on Hemaris uniformis is exceedingly opportune; from the data it may well be that it is a more northern form. But, if so, what are we to make of Mr. Hulst's assertion (for he had no material) that Floridensis is a large variety of Thysbe?-naturally, of course, of uniformis, for the band is not dentate in the Florida species. And why do we not find dentate Buffaloensis? if this is only a "small" variety, naturally, also, of uniformis. That Prof. Lintner describes the larva of Buffaloensis and appears to regard it as distinct (in letters Prof. Lintner kindly informed me he considered the imagos distinguishable) does not seem to have had any weight with Mr. Hulst, whose discovery of the relationship between uniformis and thysbe seems to have affected his proper study of these forms. I believe we may find that these are distinct species.

In view of this paper of Mr. Holland's, my list in July No. must be amended by referring occidentalis, No. 54 , as a var. to modesta, No. 53 . Further, No. 79, oreodaphne Hy. Ed., may be referred as a var. min. to No. 78 , chersis; while the position of No. 82 must be changed to follow No. 76 , drupiferarum, the name followed by a dash, as I do not know the species of which Vashti may well be a synonym, as Strecker's figure of Imperialis does not also quite agree with specimens of occidentalis, yet 
is that species, and the synonyms of this author are unusually numerous in this family.

This reduces the number of our Sphingidæ to 95, which is an ample allowance, since I have my doubts as to one or two other species not studied by me. I refer to my paper, Papilio, 2, I 72 , for notes on unidentified species of Clemens, Kirby and Boisduval. I may also refer here to my pamphlet on "The Sphingidæ of the Middle States," issued separately, which may, I hope, be of value in view of my continuous studies on this group of Lepidoptera.

\section{NOTES ON FENESICA TARQUINIUS, FABR.}

BY PROF. C. V. RILEY,

In his interesting article "On the History and the Preparatory Stages of Fenesica tarquinius" (Canadian Entomologist, xviii., pp. 141-153) Mr. Wm. H. Edwards makes some comments upon my article in Science of last April (3oth), in which I announced the carnivorous habit of the larva of this species. He has been led to do so in part by the incorrect report in Entomologica Americana of the Proceedings of the Entomological Society of Washington for January 6th last. In that report " $\mathrm{Mr}$. C. L. Johnson" is said to have observed "a lepidopterous larva feeding on a species of Aphid," but the report is incorrect both as to the fact and as to the name. Judge Lawrence C. Johnson; an old-time correspondent and for a while one of my assistants in Mississippi, was the correspondent intended, and his communication, which I was familiar with, particularly states that "he thought he saw the larva eating the plant-lice, but failed to convince himself of the fact." Mr. Lugger, in the very report quoted by $\mathrm{Mr}$. Edwards (CAN. ENT., xviii., I42, lines 2 and 3 ) expressly states that "he had never actually seen them (Fenesica larvæ) feeding upon the Aphids," and as he previously remarked that he had "made the same observations" as Mr. Johnson, the report in Entomologica Americana is inaccurate and contradictory on its face. Mr. Lugger is one of my assistants here and I knew of his observations. Mr. Edwards' statement that "all the gentlemen named had seen the larva feeding upon Aphides" is, therefore, neither justified by the facts nor by his own quotations, and whatever 